\title{
Neonatal outcome in randomized controlled trial of low dose oral misoprostol in comparison with intracervical Dinoprostone gel for labour induction
}

\author{
Savithri D. R., Suvarna R.*, Prashanthi Chennupalli, Akshatha S.
}

Department of Obstetrics and Gynecology, Kempegowda Institute of Medical Sciences, Bangalore, Karnataka, India

Received: 12 December 2017

Accepted: 18 December 2017

\section{*Correspondence:}

Dr. Suvarna R.,

E-mail: suvarna.ramaswamy@gmail.com

Copyright: (C) the author(s), publisher and licensee Medip Academy. This is an open-access article distributed under the terms of the Creative Commons Attribution Non-Commercial License, which permits unrestricted non-commercial use, distribution, and reproduction in any medium, provided the original work is properly cited.

\begin{abstract}
Background: Induction of labour is a therapeutic option when the benefits of delivery outweigh risks of continuing pregnancy. There are several agents for induction of labour to achieve better outcome of labour. Acceptable methods for induction are oxytocin infusion, dinoprostone gel, misoprostol and mechanical cervical dilators. Prostaglandins are the preferred choice in unripened cervix. To study the neonatal outcome in induction of labour with low dose oral misoprostol compared with intracervical dinoprostone gel and also to assess occurrence of meconium staining liquor. Methods: One hundred women with single live fetus, term gestation, cephalic presentation, reactive fetal heart pattern and Bishops score $<6$ were included in the study. They were randomized to receive either 6 doses of $25 \mathrm{ug}$ oral misoprostol every 3rd hourly or $0.5 \mathrm{ug}$ intracervical dinoprostone every 6th hourly for a maximum of 3 doses. Oxytocin was administered. Fetal outcome was assessed in terms of APGAR score, meconium staining and need for NICU.

Results: Meconium stained amniotic fluid was high in misoprostol group (16\%) compared to dinoprostone group (8\%). NICU admissions were seen in 7 neonates in both groups.

Conclusions: Low dose oral misoprostol is a safe method of labour induction. APGAR and NICU admission rates were comparable in both groups. Meconium staining was more in misoprostol group compared to dinoprostone group.
\end{abstract}

Keywords: APGAR, Dinoprostone, Misoprostol, Meconium staining

\section{INTRODUCTION}

Induction of labour is a therapeutic option when the benefits of delivery outweigh risks of continuing pregnancy. Inadequate cervical ripening is a known obstacle to successful labour induction and delivery. There are several agents for induction of labour to achieve better outcome of labour. Oxytocin is more effective on ripened cervix whereas prostaglandins are the preferred choice in unripened cervix.

Dinoprostone gel requires an intracervical application, needs refrigeration and is expensive. Oral misoprostol
(PGE1) has better user acceptability, does not require cold chain for storage and is cost effective.

The PGE2 preparation contains $0.5 \mathrm{mg}$ of Dinoprostone as the naturally occurring form of PGE2 which has been approved by the Food and Drug Administration in the United States for cervical ripening in patients at term or near term who have a medical or obstetric indication for induction of labour. PGE2 increases the activity of the collagenase which reaches a maximum activity at 2 hours after application in patients of multiparity and 4 hours after application in patients of nulliparity (Witter FR, 2000). ${ }^{1}$ The maximum recommended cumulative dose for 
a 24-hour period is $1.5 \mathrm{mg}$ of dinoprostone. Data regarding long term safety for foetuses exposed to PGE2 for cervical ripening are scanty. No adverse events with neonatal outcome.

Misoprostol (Cytotec Searle, Chicago, IL) is a synthetic PGE1 analogue. The FDA recognizes that in certain circumstances off-label uses of approved products like misoprostol are appropriate, rational and accepted medical practice. It can be given by oral or vaginal route. Orally administered misoprostol is rapidly absorbed and becomes intensively bound to plasma proteins, when administered vaginally peak plasma level are reached more slowly $(80 \pm 27)$ minutes than with oral administration $(34 \pm 17)$ minutes and are sustained up to 4 hours. Intrauterine pressure began to increase on an average of 8 minutes after oral administration and 25 minutes after vaginal administration and was maximal 25 minutes after oral administration and 46 minutes after vaginal administration (Goldberg BA et al). ${ }^{2}$ Misoprostol use is associated with a higher incidence of uterine hyperstimulation and thick meconium. For this reason, patient receiving misoprostol should be continuously monitored for uterine activity and foetal heart rate. Low dose misoprostol regimen will probably reduce the incidence of uterine hyperstimulation and subsequent abnormal fetal heart rate pattern and further reduce the potential need for caesarean delivery.

\section{METHODS}

A randomized control trial was done on women of reproductive age group attending labour room at KIMS Hospital and research centre, Bangalore. The study period included was from January 2015 to June 2016. The study population included 100 pregnant women admitted in labour room.

Our hospital is a tertiary referral hospital, so the rate of caesarean section is high, sample size was decided based upon the anticipated patient load and induced deliveries in the hospital by refering to previous records and by taking into consideration the inclusion and exclusion criteria.

One hundred women with single live fetus, term gestation, cephalic presentation, reactive fetal heart pattern and Bishops score $<6$ were included in the study. They were randomized to receive either 6 doses of $25 \mathrm{ug}$ oral misoprostol (study group) every 3rd hourly or $0.5 \mathrm{ug}$ intracervical dinoprostone (control group) every 6 hourly for a maximum of 3 doses.

Patients having complications like placenta previa, oligihydramnios, severe intrauterine growth restriction, parity $>5$, previous uterine surgery, cephalopelvic disproportion, renal or hepatic dysfunction, hypersensitivity to prostaglandins, premature rupture of membranes and malpresentation were excluded.
During the course of labour, partogram was obtained to assess the progress of labour. All patients were monitored half hourly for uterine contractions both for frequency and duration, and look for hypertonus, tachysystole or hyperstimulation and maternal vital signs. Continuous /intermittent fetal monitoring to assess for fetal wellbeing.

\section{RESULTS}

Mean age in Group I was 23.70 \pm 3.40 and in Group II was $23.52 \pm 3.47$. The cases in both the groups were age matched and the $\mathrm{P}$ value 0.794 was not significant.

Table 1: Patient characteristics.

\begin{tabular}{|llllll|}
\hline & & \multicolumn{2}{c}{ Group I } & \multicolumn{2}{c|}{ Group II } \\
\hline \multirow{3}{*}{ Parity } & No.mi & 32 & 64 & No. & \% \\
\hline Gestational & Multi & 18 & 36 & 20 & 60 \\
\hline age (weeks) & $37-40$ & 15 & 30 & 18 & 36 \\
\cline { 2 - 6 } & $40+1-42$ & 35 & 70 & 32 & 64 \\
\hline
\end{tabular}

Parity wise and the $\mathrm{P}=0.680$ was not significant. Gestational age in both the groups were matched and the $\mathrm{P}=0.680$ was not significant.

Indication for induction was postdatism in $70 \%$ and $64 \%$ cases of Group I and Group II in both the groups. Gestational hypertension and GDM was indication of induction in $12 \%$ each in group I and $14 \%$ each in group II. Decreased fetal movements indication for induction in $6 \%$ and $8 \%$ of cases in group I and group II respectively.

Table 2: Total number of doses distribution in two groups.

\begin{tabular}{|lllll|}
\hline \multirow{2}{*}{ No. of doses } & Group I & \multicolumn{3}{c|}{ Group II } \\
& No. & $\%$ & No. & \% \\
\hline 1 & 14 & 28.0 & 33 & 66.0 \\
\hline 2 & 18 & 36.0 & 12 & 24.0 \\
\hline 3 & 6 & 12.0 & 5 & 10.0 \\
\hline 4 & 4 & 8.0 & 0 & 0.0 \\
\hline 5 & 2 & 4.0 & 0 & 0.0 \\
\hline 6 & 6 & 12.0 & 0 & 0.0 \\
\hline Total & 50 & 100.0 & 50 & 100.0 \\
\hline
\end{tabular}

$\mathrm{P}<0.001$, significant, Fisher Exact test

In group I, it was observed that majority of cases i.e; $36 \%$ $(n=18)$ cases required 2 doses of PGE1. In group II it was observed that majority of cases i.e; $66 \%(n=33)$ required 1 dose of PGE2 gel.

In group I, $18 \%(n=9)$ cases and in group II $44 \%(n=22)$ cases required augmentation with oxytocin and $\mathrm{P}=0.005$ which was statistically significant.

In Group I, 26\% $(n=13)$ and in Group II 24\% $(n=12)$ cases underwent LSCS and $\mathrm{P}=0.817$ which was not statistically significant. 
In Group I, $16 \%(n=8)$ and in Group II $8 \%(n=4)$ cases had meconium stained amniotic fluid and $\mathrm{P}$ value was not statistically significant. Fetal distress was the most common indication for LSCS in both the groups ie.in Group I 69.2\% (n=9) and in Group II 66.7\% $(n=8)$ cases.

Table 3: Delivery details.

\begin{tabular}{|c|c|c|c|c|c|}
\hline \multirow{2}{*}{\multicolumn{2}{|c|}{$\begin{array}{l}\text { Delivery } \\
\text { details }\end{array}$}} & \multicolumn{2}{|c|}{$\begin{array}{l}\text { Group I } \\
(n=50)\end{array}$} & \multicolumn{2}{|c|}{$\begin{array}{l}\text { Group II } \\
(n=50)\end{array}$} \\
\hline & & No & $\%$ & No & $\%$ \\
\hline \multicolumn{2}{|c|}{$\begin{array}{l}\text { Augmentation with } \\
\text { oxytocin }\end{array}$} & 9 & 18.0 & 22 & 44.0 \\
\hline \multirow{2}{*}{$\begin{array}{l}\text { Mode of } \\
\text { delivery }\end{array}$} & Vaginal & 37 & 74 & 38 & 76 \\
\hline & LSCS & 13 & 26 & 12 & 24 \\
\hline \multirow{2}{*}{$\begin{array}{l}\text { Liquor } \\
\text { colour }\end{array}$} & Clear & 42 & 84 & 46 & 92 \\
\hline & Meconium & 8 & 16 & 4 & 8 \\
\hline
\end{tabular}

Table 4: APGAR score among the neonates.

\begin{tabular}{|lll|}
\hline $\begin{array}{l}\text { Mean APGAR score } \\
\text { among the neonates }\end{array}$ & Group I & Group II \\
\hline Apgar score at 1 minute & $7.5 \pm 2.1$ & $7.4 \pm 2.3$ \\
\hline Apgar score at 5 minutes & $9.4 \pm 3.6$ & $9 \pm 3.1$ \\
\hline
\end{tabular}

14 neonates required NICU. Most common reason for NICU admission was Meconium aspiration syndrome. $28.57 \%(n=2)$ in Group I and $42.85 \%(n=3)$ in Group II. In group I out of 8 cases of meconium stained liquor 2 were shifted to NICU in view of Meconium aspiration syndrome.

In group II out of 4 cases of meconium stained liquor 3 were shifted to NICU for Meconium aspiration syndrome. All 5 neonates with meconium aspiration syndrome recovered.

Table 5: Reasons for NICU admission.

\begin{tabular}{|llll|}
\hline Reasons for NICU admission & Group I & Group II & Total \\
\hline Meconium aspiration syndrome & $2(28.57 \%)$ & $3(42.85 \%)$ & $5(35.71 \%)$ \\
\hline For observation & $1(14.28 \%)$ & $1(14.28 \%)$ & $2(14.28 \%)$ \\
\hline Transient tachypnea & $1(14.28 \%)$ & $2(28.57 \%)$ & $3(21.42 \%)$ \\
\hline Gestational diabetes mellitus & $2(28.57 \%)$ & $1(14.28 \%)$ & $3(21.42 \%)$ \\
\hline Respiratory distress & $1(14.28 \%)$ & $0(0 \%)$ & $1(7.14 \%)$ \\
\hline Total & $7(100 \%)$ & $7(100 \%)$ & $14(100 \%)$ \\
\hline
\end{tabular}

$\mathrm{P}=1.000$, Not significant, Fisher Exact Test

\section{DISCUSSION}

In a similar study by Kamal $\mathrm{P}$ et al the mean age in both the groups was 23.38 and 23.36 respectively. ${ }^{3}$ In present study the mean age in both the groups was $23.70 \pm 3.40$ and $23.52 \pm 3.47$ respectively which was in accordance with the above study and difference in age was not statistically significant. Similarly, in study done by Jose $\mathrm{BL}$ et al the mean age in both the groups is $28.31 \pm 5.09$ and 28.12 \pm 4.66 and in Kulshreshtha $S$ et al study the mean age is $20 \pm 3.75$ and $25.35 \pm 3.31$ in two groups respectively and the distribution in age in two groups was not statistically significant. ${ }^{4,5}$

In present study postdatism was the most common indication for induction, $70 \%$ and $64 \%$ in Group I and Group II respectively. Parmar M et al study showed $40 \%$ and $36 \%$ cases, Greagsons et al study $95 \%$ and $94 \%$, Sheela $\mathrm{CN}$ et al study $36 \%$ and $32 \%$ cases induced for postdatism in Group I and Group II respectively. ${ }^{6-8}$

Incidence of caesarean sections was high in PGE2 group compared to PGE1 group in studies done by Jose BL et al4, Kamal $\mathrm{P}$ et al, Kulshreshtha $\mathrm{S}$ et al. ${ }^{3-5}$ Present study showed high caesarean section rate in PGE1 group compared to PGE2 group in accordance with study done by Parmar $\mathrm{M}$ et al but it was not statistically significant. ${ }^{6}$

Liquor colour at delivery was meconium stained in $12 \%$ in PGE1 group and 6\% in PGE2 group in study done by Patil P et al. ${ }^{9}$ In present study it was $16 \%$ in PGE1 and $8 \%$ in PGE2 group which was comparable.

APGAR score was better in Group I compared to Group II similar to studies done by Soilemetzidis M et al. ${ }^{10} \mathrm{Need}$ for NICU admission was similar in both the groups similar to study by Badlani $\mathrm{CN}$ et al. ${ }^{11}$ Study done by Papanikolaou EG showed more neonates were admitted to the intensive neonatal unit in the misoprostol group compared to the dinoprostone group. ${ }^{12}$

\section{CONCLUSION}

Prostaglandins provide an effective method for achieving cervical ripening. Meconium staining of liquor were seen mure in misoprostol group. The results of labour outcome convincingly prove that in the patients treated with misoprostol, incidence of caesarean section, neonatal outcome in terms of APGAR score were almost same compared to dinoprostone. 
Induction of labour with misoprostol has no adverse effects on neonatal outcome. However, it should be used judiciously with continuous fetal monitoring.

Funding: No funding sources

Conflict of interest: None declared

Ethical approval: The study was approved by the Institutional Ethics Committee

\section{REFERENCES}

1. Witter FR. Cervical ripening and labour. Clin Obstet Gynecol. 2000;43(3):469-74.

2. Goldberg AB, Greenberg MB, Darney PD. Misoprostol and pregnancy. $N$ Engl $J$ Med. 2001;344:38-47.

3. Patil Kamal P, Swamy MK, Rao Radhika K. Oral misoprostol versus intracervical dinoprostone for cervical ripening and labour induction. Journal of obstetrics and gynaecology of India. 2005;55(2):12831 .

4. Bartha JL, Comino-Delgado R, Garcia-Benasach F, Martinez-Del-Fresno P, Moreno-Corral LJ. Oral misoprostol and intracervical dinoprostone for cervical ripening and labor induction: a randomized comparison. Obstet Gynecol. 2000 Sep;96(3):465-9.

5. Kulshreshtha S, Sharma P, Mohan G, Singh SU, Singh SA. Comparative study of misoprostol vs dinoprostone for induction of labour. Indian $\mathbf{J}$ Physiol Pharmacol. 2007 Jan 20;51(1):55.

6. Parmar M, Aherwar R, Jahan I. Comparative study of $25 \mu \mathrm{g}$ vaginal misoprostol v/s cerviprime gel for induction of labour at term. Int J Reprod Contracept Obstet Gynecol. 2017 Feb 10;3(4):887-92.
7. Greagson S, Waterstone M, Norman I, Murrells T. A randomized controlled trial comparing low dose vaginal misoprostol and dinoprostone vaginal gel for inducing labour at term. BJOG. 2005;112:438-44.

8. Sheela CN, Mhaskar A, George S. Comparison of vaginal misoprostol and oral misoprostol with intracervical dinoprostol gel for induction of labour at term. J Obstet Gynecol India. 2007;57(4):327-30.

9. Patil P, Patil A. Misoprostol v/s Cerviprime Gel for Induction of Labour. Int J Med Res Rev. 2013 Jun $30 ; 1(02)$.

10. Soilemetzidis M. The effectiveness of misoprostol or dinoprostone in neonatal outcome after labour induction in post-term nulliparas. Clin Exp Obstet Gynecol. 2015;42(5):649-52.

11. Badlani CN, Shastri SS, Risbud NS. A study of vaginal misoprostol tablet versus intra cervical dinoprostone gel for the induction of labour. Int $\mathbf{J}$ Reprod Contracept Obstet Gynecol. 2017;6:1404-8.

12. Papanikolaou EG, Plachouras N, Drougia A, Andronikou S, Vlachou C, Stefos $\mathrm{T}$ et al. Comparison of misoprostol and dinoprostone for elective induction of labour in nulliparous women at full term: a randomized prospective study. Reprod Biol Endocrinol. 2004 Sep 27;2(1):70.

Cite this article as: Savithri DR, Suvarna R, Chennupalli P, Akshatha S. Neonatal outcome in randomised controlled trial of low dose oral misoprostol in comparison with intracervical dinoprostone gel for labour induction. Int J Reprod Contracept Obstet Gynecol 2018;7:165-8. 